\title{
Kajian Interkoneksi PLTM Kumbi 1.300 KW pada Sistem Lombok
}

\author{
Erwin Yusuf ${ }^{1}$, Ahmad Deni Mulyadi $^{1}$ \\ ${ }^{1}$ Departemen Teknik Konversi Energi, Politeknik Negeri Bandung \\ email : erwin.yusuf@polban.ac.id,deni_m2001@yahoo.com
}

\begin{abstract}
Abstrak
Pulau Lombok mempunyai potensi pembangkit listrik tenaga air terutama yang bersekala kecil seperti PLTM. Karena, pulau memiliki gunung Rinjani yang kawasan hutannya masih terawat dengan baik. Salah satunya adalah daerah aliran sungai Kumbi di desa Lebah Sempage, Kecamatan Narmada Kabupaten Lombok Barat. Potensi tenaga listrik yang dapat dihasilkan pada lokasi tersebut sebesar $1.300 \mathrm{~kW}$. Adapun, pembangunan pusat pembangkit dapat dilaksanakan apabila mendapat kepastian bahwa listrik yang diproduksi harus dapat tersalurkan sepenuhnya ke beban. Produksi listrik PLTM Kumbi akan disalurkan melalui Sistem Interkoneksi Lombok. Dimana, sistem interkoneksi tersebut harus mampu menyalurkan tambahan daya yang diproduksi oleh PLTM Kumbi sebesar $1.300 \mathrm{~kW}$. Sehingga diperlukan suatu kajian interkoneksi PLTM Kumbi $1.300 \mathrm{~kW}$ ke Sistem Interkoneksi Lombok. Untuk memastikan produksi listrik yang dihasilkan oleh PLTM dapat tersalurkan dengan baik. Kajian interkoneksi tersebut akan menganalisis aliran daya dan short circuit dengan menggunakan simulasi computer. Interkoneksi PLTM ke jaringan disimulasikan pada tahun 2021. Dari hasil simulasi didapatkan bahwa daya yang dihasilkan oleh PLTM dapat tersalurkan dengan baik tanpa perlu mengganti peralatan proteksi yang telah ada pada jaringan.
\end{abstract}

Kata Kunci: Energi Terbarukan, Pembangkit Listrik Tenaga Minihidro (PLTM), Distributed Generator, Aliran Daya, Hubung Singkat.

\section{PENDAHULUAN}

Pulau Lombok mempunyai Gunung Rinjani yang kawasan hutannya masih terawat dengan baik dan menghasilkan beberapa aliran sungai dengan debit yang cukup tinggi. Sehingga, pulau Lombok memiliki potensi pembangkit listrik tenaga air bersekala kecil yang melimpah, seperti pembangkit listrik tenaga mini/mikrohidro (PLTM/PLTMH). Salah satunya adalah sungai Kumbi di desa Lebah Sempage, Kecamatan Narmada Kabupaten Lombok Barat. Dengan debit dan head yang ada, potensi tenaga listrik yang dapat dihasilkan pada lokasi tersebut sebesar $1.300 \mathrm{~kW}$. Sehingga pada lokasi tersebut dapat dibangun PLTM dengan kapasitas $1.300 \mathrm{~kW}$. Adapun lokasi tersebut dapat dilihat pada gambar 1 berikut.

PLTM merupakan pembangkit listrik energi terbarukan yang telah menjadi salah satu pilihan dalam memenuhi peningkatan kebutuhan masyarakat terhadap listrik. Dimana tiap tahun semakin bertambah seiring dengan bertambahnya jumlah penduduk dan perkembangan ekonomi penduduk. Pembangkit energi terbarukan biasanya menghasilkan energi listrik dengan kapasitas kecil. Biasanya pembangkit tersebut akan diinterkoneksikan dengan jaringan distribusi (Distributed Generation $(D G)$ ) supaya dekat dengan pusat beban.

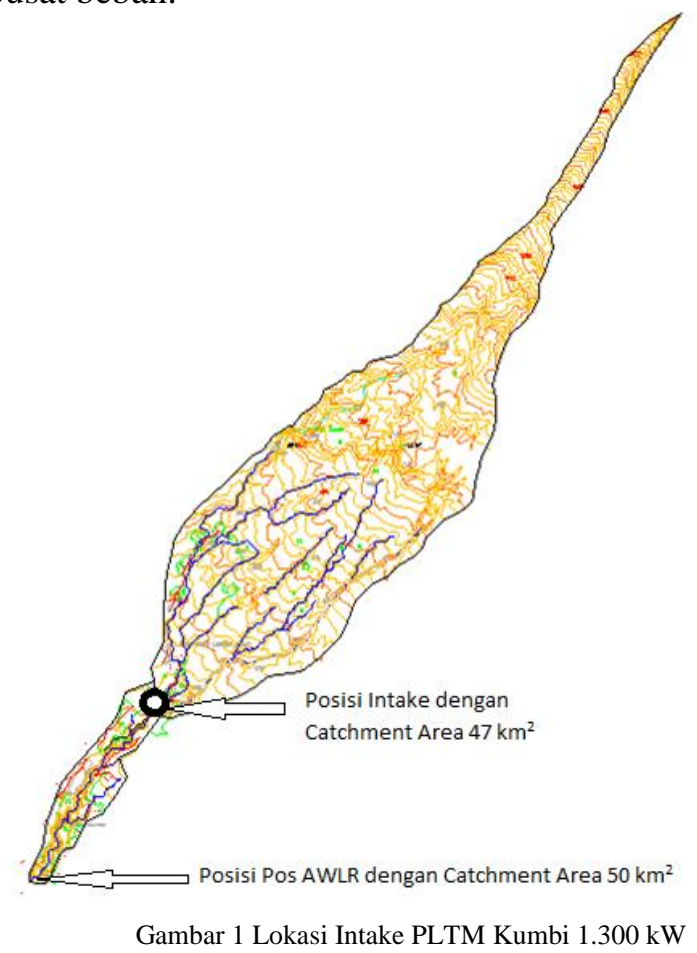


Saat ini, kebutuhan listrik di Pulau Lombok telah dilayani oleh sistem interkoneksi $150 \mathrm{kV}$. Sistem Interkoneksi Lombok $150 \mathrm{kV}$ ini telah beroperasi sejak 2013 setelah pembangkit listrik Jeranjang unit 3 (1x25 MW) dioperasikan untuk memasok beban Mataram. Sistem ini telah diperluas ke Lombok Timur setelah transmisi $150 \mathrm{kV}$ Jeranjang - Sengkol - Selong Pringgabaya selesai pada tahun 2014. Sehingga saat ini, sistem interkoneksi $150 \mathrm{kV}$ meliputi gardu induk Ampenan, Jerajang, mantang, Sengkol, Kuta, Pakamontong / Selong dan Pringbaya. Sistem Lombok ini akan terus dikembangkan seperti ditunjukkan pada gambar 2 [1].

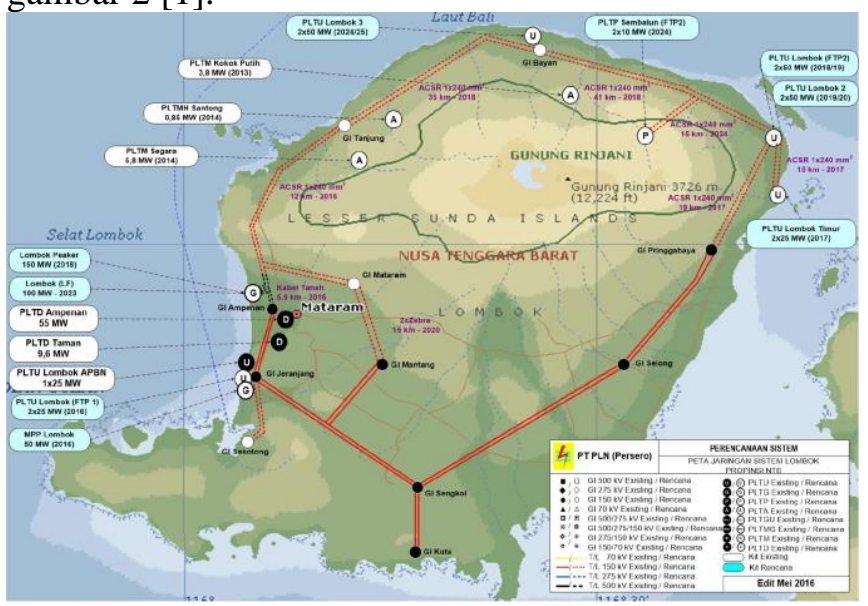

Gambar 2 Rencana Pengembangan Sistem Interkoneksi Lombok 2016-2025

Kebutuhan listrik di kecamatan Narmada telah dilayani oleh sistem Lombok melalui GI Ampenan 150/20 kV dan GI Mantang. PLTM $1.300 \mathrm{~kW}$, agar dapat menyalurkan listriknya ke konsumen, akan dinterkoneksikan pada jaringan distribusi $20 \mathrm{kV}$ yang di GI Ampenan.

Pembangunan pusat pembangkit dapat dilaksanakan apabila mendapat kepastian bahwa listrik yang diproduksi dapat tersalurkan sepenuhnya ke beban. Selain itu, jaringan distribusi tersebut harus mampu menyalurkan tambahan daya yang diproduksi oleh PLTM Kumbi $1.300 \mathrm{~kW}$. Sehingga diperlukan suatu kajian interkoneksi PLTM Kumbi 1.300 kW ke sistem Lombok. Kajian ini dilakukan untuk memastikan produksi listrik yang dihasilkan oleh PLTM dapat tersalurkan dengan baik.

\section{RUMUSAN MASALAH}

Untuk memastikan produksi listrik yang dihasilkan oleh PLTM dapat tersalurkan dengan baik, maka diperlukan kajian interkoneksi PLTM ke jaringan interkoneksi. Dimana, kajian interkoneksi itu terdiri dari kajian aliran daya dan kajian arus hubung singkat untuk koordinasi peralatan proteksi [2].

Dengan kajian tersebut, beberapa kriteria penyambungan pembangkit listrik baru ke jaringan dapat di analisis. Adapun kriteria tersebut sebagai berikut [3]:

1. Tingkat kualitas layanan sebelum dan sesudah interkoneksi,

2. Perlu tidaknya penambahan kompensator,

3. Penanggulangan Tegangan Gangguan,

4. Rating peralatan yang ada harus dapat melebihi kapasitas arus hubung singkat.

\section{A. Aliran Daya}

Perhitungan aliran daya pada dasarnya adalah menghitung besar tegangan dan sudut phasa setiap bus pada kondisi tunak dan dengan beban seimbang. Hasil perhitungan ini dilakukan untuk mengukur daya aktif dan daya reaktif yang mengalir pada jaringan. Besarnya daya aktif dan daya reaktif pada jaringan ditentukan oleh daya yang dibangkitkan pembangkit serta rugi-rugi daya pada jaringan.

Perhitungan aliran daya diperlukan untuk melihat tersalurkannya atau tidak daya yang dibangkitkan oleh PLTM Kumbi dalam sistem tenaga.

Sistem tenaga listrik terdiri dari beberapa bus. Setiap bus dalam sistem tenaga listrik dikelompokkan menjadi 3 tipe bus, yaitu:

- Bus beban (bus PQ), pada bus beban besaran variabel daya aktif dan daya Reaktif telah diketahui, sedangkan besar tegangan dan sudut phasanya dihitung.

- Bus generator (bus P-V), pada bus generator besaran variabel tegangan dan daya aktif telah diketahui, sedangkan sudut phasa tegangan dan daya reaktif dihitung.

- Bus ayun (swing/slack), pada bus ayun besaran variabel tegangan dan sudut phasanya telah diketahui, sudut phasa pada bus referensi menjadi acuan untuk sudut phasa tegangan pada bus yang lain. Konsep bus ayun dalam aliran beban berguna untuk menanggung seluruh rugi-rugi daya yang terjadi pada jaringan.

Ada beberapa metode untuk menyelesaikan perhitungan aliran daya, diantaranya adalah; metode Gauss Seidel, metode Newton Rapshon, dan Metode Fast-Decoupled. Adapun untuk menyelesaikan persamaan aliran daya pada penelitian ini metode yang digunakan adalah metode Newton-Raphson [3][5]. Dengan metode Newton-Raphson persamaan aliran 
daya dinyatakan bahwa tegangan bus dan admitansi saluran dalam bentuk polar, seperti pada Persamaan (1) dan (2).

$P_{i}=V_{i}^{*} \sum_{n=1}^{n} Y_{i n} V_{n}$

$Q_{i}=-\operatorname{Im}\left\{V_{i}^{*} \sum_{n=1}^{n} Y_{i n} V_{n}\right\}$

dimana $P_{i}$ adalah besar daya aktif pada bus ke-i; $Q_{i}$ adalah besar daya reaktif pada bus ke-i; $\mathrm{V}_{\mathrm{i}}^{*}$ adalah besar tegangan pada bus kei; $\mathrm{V}_{\mathrm{n}}$ adalah besar tegangan pada bus ke-n; dan $Y_{\text {in }}$ adalah besar admitansi antara bus ke-i dan bus ke-n.

Hasil perhitungan daya menggunakan Persamaan (1) dan (2) akan diperoleh nilai $P_{1}^{(k)}$ dan $Q_{1}^{(k)}$. Hasil ini digunakan untuk menghitung nilai $\Delta \mathrm{P}_{1}^{(\mathrm{k})}$ dan $\Delta \mathrm{Q}_{1}^{(\mathrm{k})}$ menggunakan persamaan berikut:

$\Delta P_{1}^{(k)}=P_{i \text { spec }}-P_{i \text { calc }}^{(k)}$

$\Delta Q_{1}^{(k)}=Q_{i \text { spec }}-Q_{i \text { calc }}^{(k)}$

dimana $P_{i}^{(k)}$ calc adalah besar daya aktif perhitungan pada bus ke-i; $\mathrm{P}_{\mathrm{i} \text { spec }}$ adalah besar daya aktif yang diketahui pada bus ke-i; $Q_{i \text { calc }}^{(\mathrm{k})}$ adalah besar daya reaktif perhitungan pada bus ke-i; $Q_{i \text { spec }}$ besar daya reaktif yang diketahui pada bus ke-i.

Hasil perhitungan Persamaan (3) dan (4) digunakan untuk membentuk matriks Jacobian, persamaan matriks Jacobian dapat dilihat pada Persamaan (5).

$\left[\begin{array}{l}\Delta P^{(k)} \\ \Delta Q^{(k)}\end{array}\right]=\left[\begin{array}{ll}J_{1} & J_{2} \\ J_{3} & J_{4}\end{array}\right]\left[\begin{array}{c}\Delta \delta^{(k)} \\ \Delta|V|^{(k)}\end{array}\right]$

Setelah nilai $\Delta \delta^{(k)}$ dan $\Delta|V|^{(k)}$ didapat, lalu menghitung nilai tersebut untuk iterasi berikutnya, yaitu dengan menambahkan nilai $\Delta \delta_{i}^{(k)}$ dan $\Delta\left|V_{i}^{(k)}\right|$, sehingga diperoleh persamaan (6) dan (7).

$\delta_{i}^{(k+1)}=\Delta \delta^{(k)}-\Delta \delta_{i}^{(k)}$

$\left|V_{i}^{(k+1)}\right|=\left|V_{i}^{(k)}\right|-\Delta\left|V_{i}^{(k)}\right|$

Hasil perhitungan Persamaan (6) dan (7). digunakan lagi untuk proses iterasi selanjutnya, yaitu dengan memasukkan nilai ini ke dalam Persamaan (1) dan (2) sebagai langkah awal perhitungan aliran daya. Proses ini dilakukan terus menerus yaitu n-iterasi sampai diperoleh nilai yang konvergen.

\section{B. Arus Hubung Singkat}

Kajian arus hubung singkat diperlukan untuk memeriksa atau memilih rating peralatan dan menentukan pengaturan relay. Hubung singkat sendiri dalam sistem ketenagalistrikan berupa sambungan tidak normal (termasuk arc) dengan impedansi yang relatif rendah, baik disengaja maupun tidak disengaja antara dua titik dengan potensi yang berbeda. Hubung singkat biasanya juga disebut gangguan atau gangguan hubung singkat. Gangguan hubung singkat dapat terjadi akibat adanya isolasi yang tembus atau rusak karena tidak tahan terhadap tegangan lebih, baik yang berasal dari dalam maupun yang berasal dari luar (akibat sambaran petir).

Dalam keadaan gangguan hubung singkat, arus yang mengalir pada jaringan melampaui batas arus kerja (arus nominal) dari suatu sistem. Gangguan hubung singkat ini tidak hanya merusak peralatan atau elemenelemen sirkuit yang dilaluinya, tetapi juga dapat juga menyebabkan kenaikan tegangan pada phasa yang tidak terganggu dan dapat menyebabkan tegangan lebih pada tempat-tempat tertentu.

Bila gangguan hubung singkat dibiarkan berlangsung dengan lama pada suatu sistem daya, banyak pengaruh- pengaruh yang tidak diinginkan yang dapat terjadi [6]:

1. Berkurangnya batas-batas kestabilan untuk sistem daya.

2. Rusaknya perlengkapan yang berada dekat dengan gangguan yang disebabkan oleh arus tak seimbang, atau tegangan rendah yang ditimbulkan oleh hubung singkat.

3. Ledakan-ledakan yang mungkin terjadi pada peralatan yang mengandung minyak isolasi sewaktu terjadinya suatuhubung singkat, dan yang mungkin menimbulkan kebakaran sehingga dapat membahayakan orang yang menanganinya dan merusak peralatan - peralatan yang lain.

4. Terpecah-pecahnya keseluruhan daerah pelayanan sistem daya itu oleh suatu rentetan tindakan pengamanan yang diambil oleh sistem - sistem pengamanan yang berbeda - beda; kejadian ini dikenal sebagai "cascading".

Ada beberapa jenis gangguan hubung singkat atau short circuit pada sistem tenaga listrik, yaitu:

1. Simetri atau seimbang
a. Tiga phasa (LLL)
b. Tiga phasa ke tanah (LLLG)

2. Tidak simetri atau tidak seimbang
a. Satu phasa ke tanah (LG)
b. Dua phasa ke tanah (LLG) 
c. Antar phasa (LL)

Gangguan Hubung Singkat Satu Phasa ke Tanah

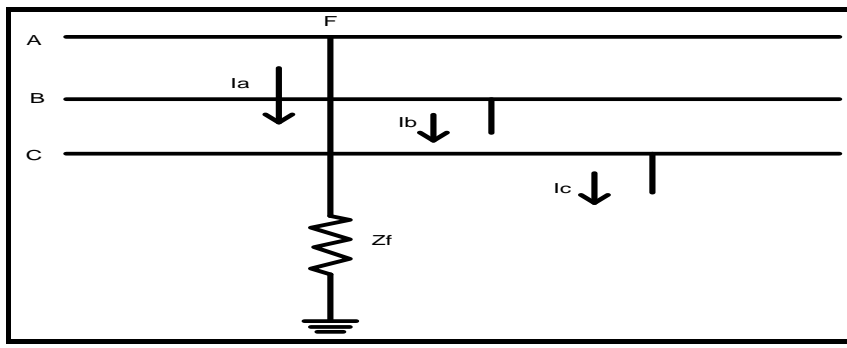

Gambar 3 Gangguan Satu Phasa ke Tanah

Pada Gambar 3 diatas menunjukkan rangkaian pengganti akibat dari hubung singkat Satu Phasa ke Tanah sehingga muncul Impedansi gangguan $\left(\mathrm{Z}_{\mathrm{f}}\right)$

Persamaan Awal

$\mathrm{V}_{\mathrm{a} 1}=\mathrm{V}_{\mathrm{f}}-\mathrm{I}_{\mathrm{a} 1} \cdot \mathrm{Z}_{1}$

$\mathrm{V}_{\mathrm{a} 2}=-\mathrm{I}_{\mathrm{a} 2} \cdot \mathrm{Z}_{2}$

$\mathrm{V}_{\mathrm{a} 0}=-\mathrm{I}_{\mathrm{a} 0} \cdot \mathrm{Z}_{0}$

Persamaan pada saat gangguan phasa ke tanah :

$\mathrm{I}_{\mathrm{b}}=0$

$\mathrm{I}_{\mathrm{c}}=0$

$\mathrm{V}_{\mathrm{a}}=\mathrm{I}_{\mathrm{a}} \cdot \mathrm{Z}_{\mathrm{f}}$

Dari persamaan diatas didapatkan persamaan arus gangguan hubung singkat satu phasa ke tanah.

$I_{\text {fault }}=\frac{3 V}{\left(Z_{1}+Z_{2}+Z_{0}\right)+3 Z_{f}}$

\section{Gangguan Hubung Singkat Dua Phasa}

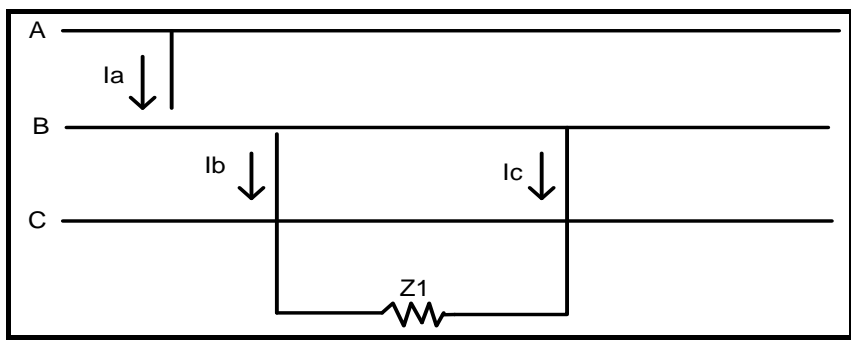

Gambar 4 Gangguan Dua Phasa

Pada Gambar 4. diatas menunjukkan rangkaian pengganti akibat dari hubung singkat Dua Phasa sehingga muncul Impedansi gangguan $\left(\mathrm{Z}_{1}\right)$.

Persamaan pada kondisi fault yaitu :

$\mathrm{I}_{\mathrm{b}}=0$

$\mathrm{I}_{\mathrm{b}}=\mathrm{I}_{\mathrm{c}}$

$\mathrm{V}_{\mathrm{b}}-\mathrm{V}_{\mathrm{c}}=\mathrm{I}_{\mathrm{b}} \cdot \mathrm{Z}_{\mathrm{f}}$

Dari persamaan diatas diperoleh persamaan arus hubung singkat dua phasa sebagai berikut:

$$
\mathrm{I}_{\text {fault }}=\frac{-j \sqrt{3} V f}{Z_{1}+Z_{2}+Z_{f}}
$$

\section{Gangguan Hubung Singkat Dua Phasa ke Tanah}

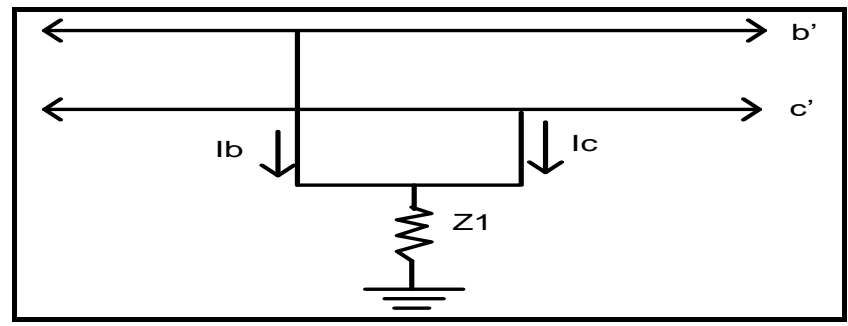

Gambar 5 Gangguan Dua Phasa ke Tanah

Pada

gambar 5 diatas menunjukkan rangkaian pengganti akibat dari hubung singkat Dua Phasa ke Tanah sehingga muncul Impedansi gangguan $\left(\mathrm{Z}_{1}\right)$.

$$
\mathrm{I}_{\text {fault }}=\frac{V_{f}}{Z_{1}+\frac{Z_{2}\left(Z_{0}+3 Z_{f}\right)}{Z_{2}+Z_{0}+3 Z_{f}}}
$$

\section{Gangguan Hubung Singkat Tiga Phasa}

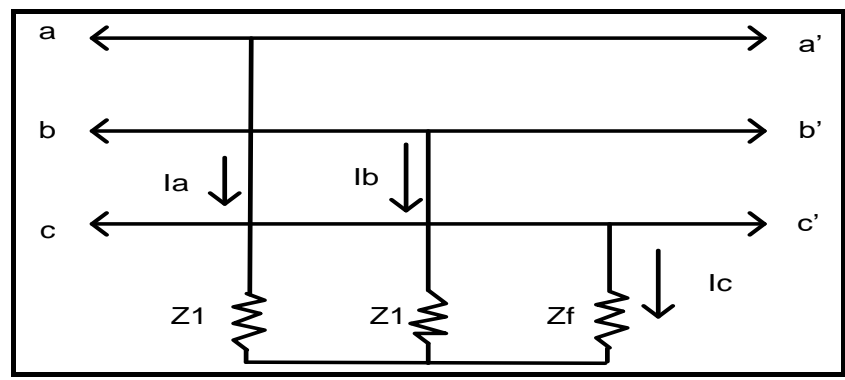

Gambar 6 Gangguan Tiga Phasa

Pada Gambar 6 diatas menunjukkan rangkaian pengganti akibat dari hubung singkat tiga phasa sehingga muncul Impedansi gangguan $\left(Z_{1}\right)$ pada setiap phasanya. Sehingga persamaan arus gangguan hubung singkatnya yaitu :

$\mathrm{I}_{\mathrm{a}}=\mathrm{I}_{1}=\frac{V a}{Z 1+Z f}$

$\mathrm{I}_{\mathrm{b}}=a^{2} \mathrm{I}_{1}$

$\mathrm{I}_{\mathrm{c}}=a \mathrm{I}_{1}$

\section{STUDI INTERKONEKSI PLTM KUMBI}

\section{A. Proyeksi Neraca Energi}

Proyeksi kebutuhan beban dan rencana penambahan kapasitas pembangkit di sistem Lombok periode tahun 
2016-2025 terdapat pada neraca daya sesuai Tabel 1 [1].

Selama periode tersebut, direncanakan penambahan pembangkit baru dengan kapasitas total sekitar 730 MW dan reserve margin (RM) cukup tinggi berkisar antara 38\% sampai $97 \%$. Kondisi reserve margin $97 \%$ terjadi pada tahun 2019 dikarenakan adanya penugasan dari Pemerintah untuk program pembangunan pembangkit $35 \mathrm{GW}$ yang harus diselesaikan pada tahun 2019.

TABEL 1

PROYEKSI NERACA ENERGI PADA SISTEM LOMBOK

\begin{tabular}{|c|c|c|c|c|c|c|c|c|c|c|c|}
\hline PROYEK & Unit & 2016 & 20172 & 20182 & 20192 & 20202 & 20212 & 20222 & 20232 & 20242 & 2025 \\
\hline \multicolumn{12}{|l|}{ KEBUTUHAN } \\
\hline Produksi Energi & GWh & 1,290 & 1,459 & 1,6231 & 1,779 & 1,918 & 2,0672 & 2,226 & 2,3932 & 2,5622 & 2,743 \\
\hline Load Factor & $\%$ & 65 & 66 & 67 & 68 & 68 & 69 & 70 & 71 & 71 & 72 \\
\hline Beban Puncak & MW & 225 & 252 & 277 & 300 & 320 & 341 & 364 & 387 & 410 & 434 \\
\hline \multicolumn{12}{|l|}{ PASOKAN } \\
\hline Kapasitas Terpasang & MW & 274 & 222 & 130 & 130 & 100 & 40 & 40 & 40 & 40 & 40 \\
\hline Daya Mampu Netto & & 238 & 186 & 125 & 125 & 95 & 35 & 35 & 35 & 35 & 35 \\
\hline Kapasitas Terpasang PLN & & 119 & 119 & 27 & 27 & 27 & 27 & 27 & 27 & 27 & 27 \\
\hline IPP & & 13 & 13 & 13 & 13 & 13 & 13 & 13 & 13 & 13 & 13 \\
\hline SEWA & & 142 & 90 & 90 & 90 & 60 & 0 & 0 & 0 & 0 & 0 \\
\hline Retired \& Mothballed & & 0 & 62 & 0 & 0 & 0 & 0 & 0 & 0 & 0 & 0 \\
\hline \multicolumn{12}{|l|}{ Tambahan Kapasitas } \\
\hline \multicolumn{12}{|l|}{ SEWA } \\
\hline PLTU Sewa Lombok & & & & & $50 *)$ & & & & & & \\
\hline \multicolumn{12}{|l|}{ PLN ON GOING \& COMMITTED } \\
\hline Lombok (FTP1) & PLTU & 50 & & & & & & & & & \\
\hline Lombok Peaker & PLTGU/MGU & & & 150 & & & & & & & \\
\hline MPP Lombok & PLTG/MG & 50 & & & & & & & & & \\
\hline \multicolumn{12}{|l|}{ IPP ON GOING \& COMMITTED } \\
\hline Lombok Timur & PLTU & & 50 & & & & & & & & \\
\hline PLTM Tersebar & PLTM & & & 1 & 2 & - & & - & - & - & \\
\hline \multicolumn{12}{|c|}{ RENCANA TAMBAHAN KAPASITAS } \\
\hline Lombok (FTP2) & PLTU & & & 50 & 50 & & & & & & \\
\hline Lombok 2 & PLtu & & & & 50 & 50 & & & & & \\
\hline Lombok 3 & PLTU & & & & & & & & & 50 & 50 \\
\hline Lombok (Load Follower) & PLTGU & & & & & & & & 100 & & \\
\hline Sembalun (FTP2) & PLTP & & & & & & & & & 20 & \\
\hline PLTSa Tersebar & PLTSa & & 1 & & & & & & & - & \\
\hline PLTBM Tersebar & PLTBM & & & - & & - & 5 & - & - & - & 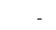 \\
\hline TOTAL TAMBAHAN KAPASITAS & MW & 100 & 51 & 201 & 102 & 50 & 5 & 0 & 100 & 70 & 50 \\
\hline TOTAL KAPASITAS SISTEM & MW & 374 & 373 & 482 & 584 & 604 & 549 & 549 & 649 & 719 & 769 \\
\hline TOTAL DAYA MAMPU NETTO & MW & 338 & 336 & 476 & 578 & 598 & 538 & 538 & 638 & 708 & 758 \\
\hline RESERVED MARGIN (RM) & $\%$ & 50 & 33 & 72 & 93 & 87 & 58 & 48 & 65 & 73 & 75 \\
\hline
\end{tabular}

\section{B. Perencanaan Penambahan Pembangkit}

Berdasarkan proyeksi neraca energi diatas, sebaiknya interkoneksi PLTM Kumbi dilakukan setelah tahun 2019. Hal ini dilakukan untuk menghindari tidak terserapnya daya yang dihasilkan pada tahun tersebut. Waktu interkoneksi PLTM Kumbi yang paling tepat adalah pada tahun 2021. Dengan asumsi terlambatnya interkoneksi Lombok Peaker 150 MW.

\section{Studi Interkoneksi Pembangkit pada Sistem \\ Lombok melalui Jaringan GH Panaraga1}

Berdasarkan diagram interkoneksi sistem Lombok seperti yang ditunjukkan pada gambar 7. Saat ini, kebutuhan beban Narmada dilayani oleh Sistem Interkoneksi Lombok $150 \mathrm{kV}$ melalui GI Ampenan dan GI Mantang. Saat ini GI Ampenan memliki 2 unit trafo $150 / 20 \mathrm{kV}$, trafo 1 dan trafo 2. Adapun Beban Narmada terhubung pada Trafo 2. Selain melayani beban Narmada, trafo 2 juga melayani beban Perumnas, P. Batudawa dan Taman. Pada Trafo 2 ini juga terhubung kepada PLTD Ampenan dan PLTD Taman serta beberapa PLTMH seperti PLTMH Sesaot dan PLTMH Cakra.

Sedangkan beban Narmada dan GI Ampenan dihubungkan oleh GH Panaraga1. GH Panaraga1 ini terhubung pada 2 bus beban, diantaranya beban Panaragal dan beban Narmada. Berdasarkan jarak dan ketersediaan jaringan, PLTM Kumbi untuk menyalurkan energi listriknya akan terhubung pada GH Panaraga1. Adapun jarak yang dibutuhkan ke jaringan tie in $20 \mathrm{kV}$ Panaraga sejauh $1 \mathrm{~km}$.

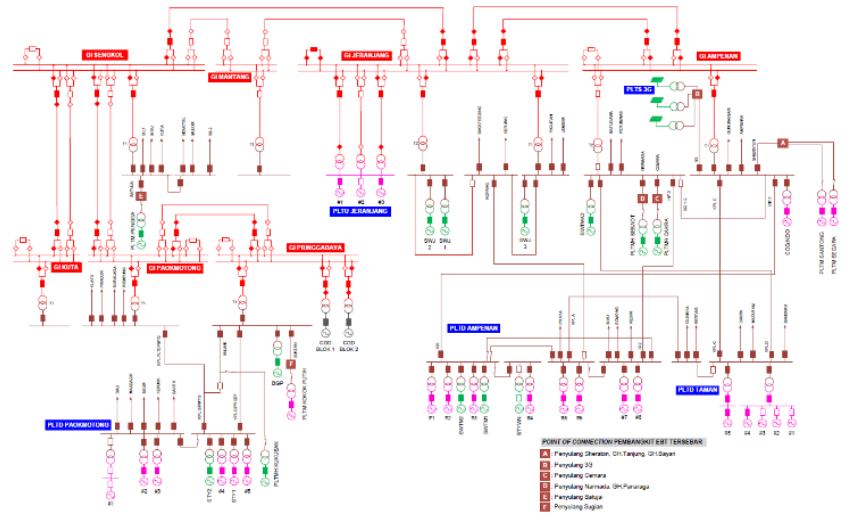

Gambar 7 Diagram Sistem Interkoneksi Lombok 150 kV (Sumber: PT PLN (Persero)-Cabang Lombok)

\section{Data Peralatan Jaringan Distribusi 20kV Panaraga}

\section{Jalur Distribusi}

Jalur distribusi terdiri dari kawat 3 (tiga) phasa dengan luas penampang $158 \mathrm{~mm}^{2}$. Adapun, tinggi tiang dari tanah ke kawat sebesar 14 meter.

\section{Peralatan Proteksi}

Berdasarkan hasil survey, data short circuit breaking capacity dan short circuit making circuit peralatan yang terpasang di jaringan $20 \mathrm{kV}$ Panaraga adalah seperti yang ditunjukkan pada Tabel 2 dibawah ini.

TABEL 2

DATA PERALATAN PROTEKSI PADA JARINGAN 20 KV PANARAGA

\begin{tabular}{lcrr}
\hline No & $\begin{array}{c}\text { Jenis } \\
\text { Pemutus }\end{array}$ & $\begin{array}{c}\text { Short Circuit } \\
\text { Breaking } \\
\text { Capacity }\end{array}$ & $\begin{array}{c}\text { Short Circuit } \\
\text { Making } \\
\text { Capacity }\end{array}$ \\
\hline \hline 1 & LBS & $25 \mathrm{kA}$ & $63 \mathrm{kA}$
\end{tabular}




\begin{tabular}{llrr}
\hline No & \multicolumn{1}{c}{$\begin{array}{c}\text { Jenis } \\
\text { Pemutus }\end{array}$} & $\begin{array}{c}\text { Short Circuit } \\
\text { Breaking } \\
\text { Capacity }\end{array}$ & $\begin{array}{c}\text { Short Circuit } \\
\text { Making } \\
\text { Capacity }\end{array}$ \\
\hline 2 & PMT & $25 \mathrm{kA}$ & $63 \mathrm{kA}$ \\
3 & Recloser & $12,5 \mathrm{kA}$ & $31,5 \mathrm{kA}$ \\
\hline
\end{tabular}

\section{SIMULASI DAN ANALISIS}

\section{A. Analisis Aliran Daya}

Analisis aliran daya dilakukan dengan menggunakan simulasi program komputer, diagram alirnya ditampilkan pada gambar 8 .

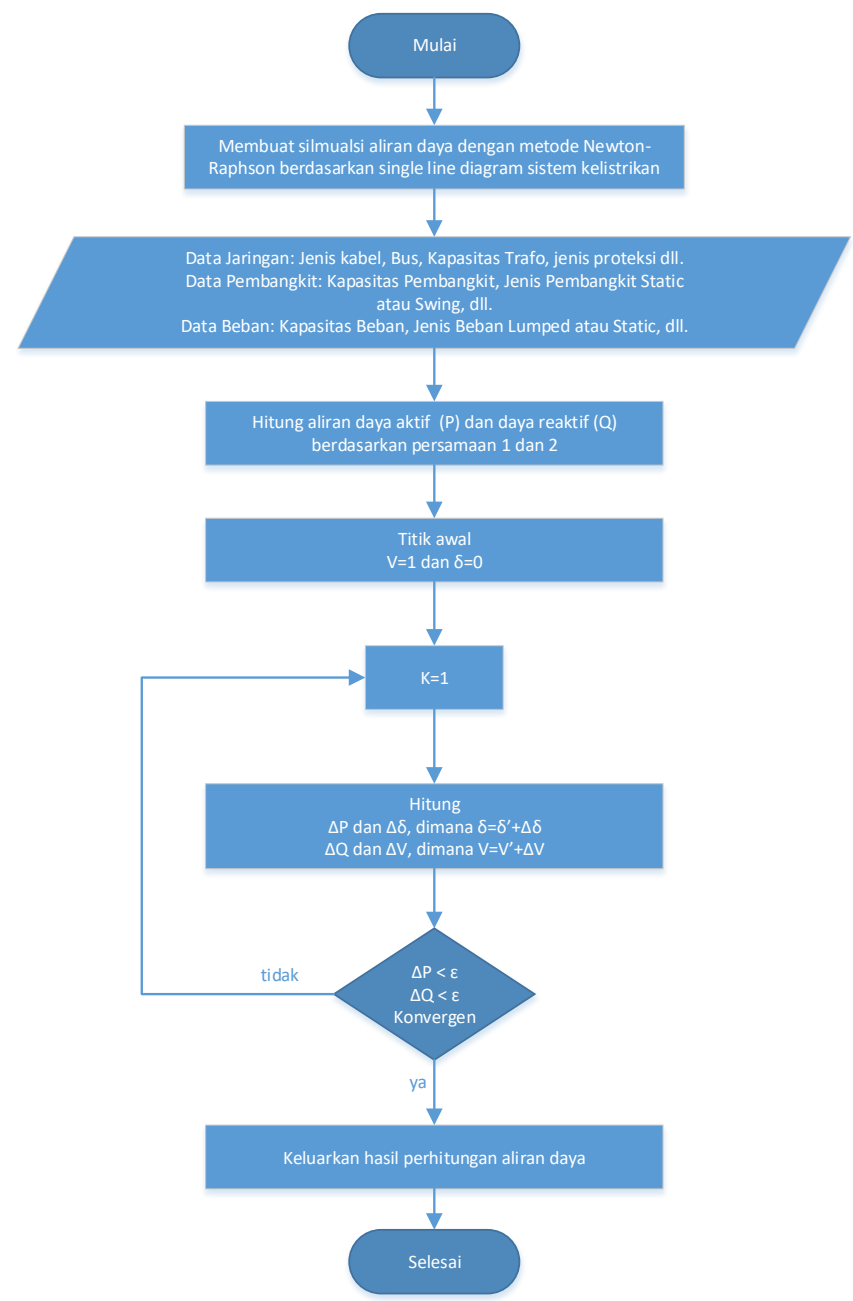

Gambar 8 Diagram Alir Simulasi Studi Aliran Daya Sistem Lombok dengan Masuknya PLTM Kumbi

Simulasi aliran daya ini dilakukan pada proyeksi tahun 2021. Dimana beban puncak pada Sistem Interkoneksi Lombok saat itu sebesar 341MW. Mengingat PLTM sebagai pembangkit terbarukan yang dibangun untuk menggantikan peran PLTD. Maka pada simulasi ini ada beberapa PLTD yang tidak diaktifkan. Terutama beberapa unit dari PLTD Taman dan PLTD Ampenan. Simulasi ini juga mengasumsikan terlambatnya interkoneksi Lombok Peaker 150 MW.

Simulasi aliran daya dilakukan pada dua keadaan. Pertama adalah simulasi aliran daya sebelum PLTM Kumbi masik ke jaringan interkoneksi. Kedua adalah simulasi aliran daya setelah PLTM Kumbi masuk ke jaringan.

Berdasarkan diagram alir pada gambar 8, maka didapatkan hasil simulasi yang ditampilkan pada gambar 9, Tabel 3 dan Tabel 4.

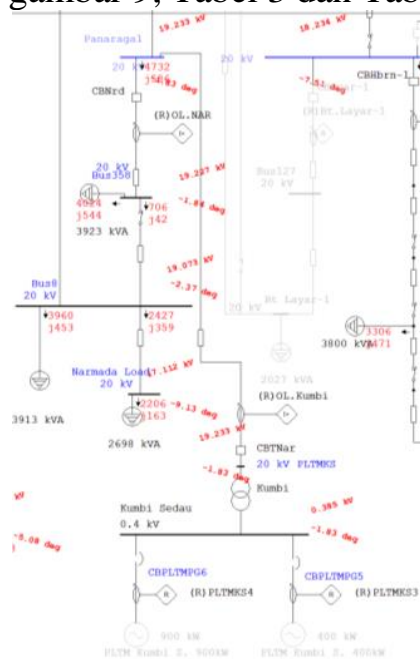

(a). Sebelum Interkoneksi Kumbi

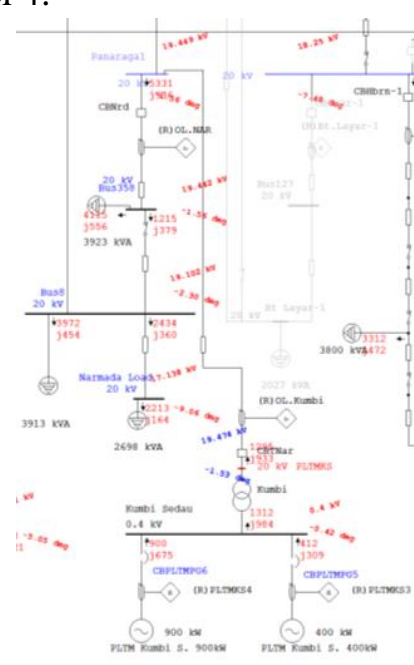

(b). Setelah Interkoneksi Kumbi
Gambar 9 Simulasi Aliran Daya PLTM Kumbi dengan ETAP

Terlihat pada gambar 9, pada tahun 2021, PLTM Kumbi akan diinterkoneksikan pada bus Panaraga1. Dimana, bus tersebut melayani beban Panaragal dan beban Narmada.

Berdasarkan hasil survey, bus beban Narmada terdiri dari 2 beban. Pada tahun 2021 beban 1 membutuhkan daya sebesar 3.913 kVA sedangkan beban 2 membutuhkan $2.698 \mathrm{kVA}$. Kedua beban tersebut dilayani oleh GI Ampenan dan GI Mantang. Dari simulasi yang hasilnya ditunjukkan pada tabel 3. GI Ampenan melalui GH Panaragal memenuhi $706 \mathrm{~kW}$ daya nyata dan $42 \mathrm{kVAR}$ daya reaktif dan GI Mantang memenuhi $5.688 \mathrm{~kW}$ daya nyata dan $745 \mathrm{kVAR}$ daya reaktif.

TABEL 3

ALIRAN DAYA ANTAR BUS GI SEBELUM INTERKONEKSI PLTM KUMBI

\begin{tabular}{rlrr}
\hline Dari & \multicolumn{1}{c}{ Ke } & P (kW) & Q (kVAR) \\
\hline \hline G1 Ampenan & Perumnas & 3.969 & 667 \\
GI Ampenan & P. Batudawa & 1.071 & 226 \\
GI Ampenan & Taman & 6.270 & 1.387
\end{tabular}




\begin{tabular}{llrr}
\hline \multicolumn{1}{c}{ Dari } & \multicolumn{1}{c}{ Ke } & P (kW) & Q (kVAR) \\
\hline \hline GI Ampenan & GH Panaraga1 & 4.843 & 719 \\
GI Mantang & Narmada & 5.688 & 745 \\
GH Panaraga1 & Panaraga & 4.024 & 544 \\
GH Panaraga1 & Narmada & 706 & 42 \\
Kumbi & GH Panaraga1 & & \\
\hline
\end{tabular}

\begin{tabular}{lrrr}
\hline \multicolumn{1}{c}{ Bus } & $\begin{array}{c}\text { Tegangan } \\
(\mathbf{k V )}\end{array}$ & $\begin{array}{c}\text { Tegangan } \\
(\%)\end{array}$ & $\begin{array}{c}\text { Sudut Phasa } \\
(\text { derajat })\end{array}$ \\
\hline \hline B. Panaraga1 & 19.227 & 96.13 & -1.84 \\
Kumbi & 19.233 & 96.16 & -1.83 \\
\hline
\end{tabular}

Sedangkan pada tabel 4, memperlihatkan aliran daya pada bus beban Narmada pada tahun 2021 setelah interkoneksi PLTM Kumbi. Pada tahu tersebut, kebutuhan beban Narmada dilayani oleh GI Ampenan melalui GH Panaraga1 memenuhi $1.215 \mathrm{~kW}$ daya nyata dan 379 kVAR daya reaktif dan GI Mantang memenuhi $5.209 \mathrm{~kW}$ daya nyata dan $424 \mathrm{kVAR}$ daya reaktif. Aliran daya dari GI Mantang menjadi berkurang diakibatkan adanya tambahab pasokan dari PLTM Kumbi sebesar $1.295 \mathrm{~kW}$ melalui $\mathrm{GH}$ Panaraga1. Selain meningkatkan pasokan daya ke beban Narmada, PLTM Kumbi juga dapat meningkatkan pasokan ke beban Panaragal. Pasokan daya ke beban tersebut $4.024 \mathrm{~kW}$ daya nyata 544 kVAR daya reaktif sebelum interkoneksi, menjadi $4.115 \mathrm{~kW}$ daya nyata $556 \mathrm{kVAR}$ daya reaktif setelah interkoneksi PLTM Kumbi.

TABEL 4

ALIRAN DAYA ANTAR BUS GI SESUDAH INTERKONEKSI PLTM KUMBI

\begin{tabular}{llrr}
\hline \multicolumn{1}{c}{ Dari } & \multicolumn{1}{c}{ Ke } & P (kW) & Q (kVAR) \\
\hline \hline G1 Ampenan & Perumnas & 3.998 & 672 \\
GI Ampenan & P. Batudawa & 1.078 & 228 \\
GI Ampenan & Taman & 6.314 & 1.397 \\
GI Ampenan & GH Panaraga & 4.116 & 93 \\
GI Mantang & Narmada & 5.209 & 424 \\
GH Panaraga1 & Panaraga & 4.115 & 556 \\
GH Panaraga1 & Narmada & 1.215 & 379 \\
Kumbi & GH Panaraga & 1.295 & 933 \\
\hline
\end{tabular}

Berdasarkan simulasi aliran daya baik sebelum atau setelah interkoneksi PLTM Kumbi, menunjukkan bahwa kualitas tegangan pada pengumpan JTM Narmada masih dalam batasan kriteria operasi yaitu masih diantara 90\% -105\% dari tegangan nominal.

TABEL 5

KuAltTAS TEGANGAN Bus SEBELUM INTERKONEKSI PLTM KuMBI

\begin{tabular}{lrrr}
\hline \multicolumn{1}{c}{ Bus } & $\begin{array}{c}\text { Tegangan } \\
(\mathbf{k V})\end{array}$ & $\begin{array}{c}\text { Tegangan } \\
(\%)\end{array}$ & \multicolumn{1}{c}{$\begin{array}{c}\text { Sudut Phasa } \\
\text { (derajat) }\end{array}$} \\
\hline \hline G1 Ampenan & 19.763 & 98.81 & -0.23 \\
Perumnas & 18.825 & 94.13 & -3.39 \\
P. Batudawa & 19.747 & 98.74 & -0.27 \\
Taman & 19.512 & 97.56 & -0.45 \\
GH Panaraga1 & 19.233 & 96.16 & -1.83 \\
B. Narmada & 19.073 & 95.36 & -2.37
\end{tabular}




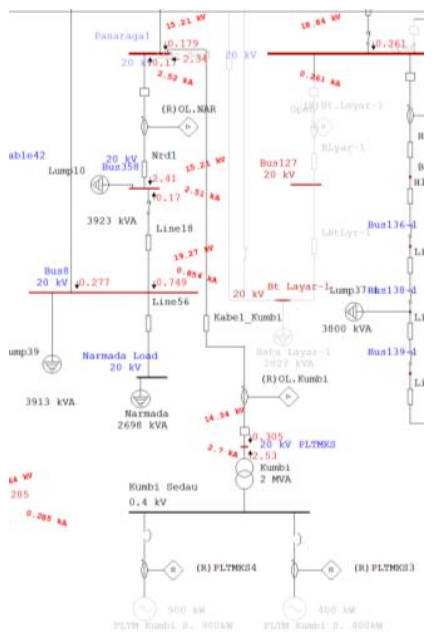

(a). Sebelum Interkoneksi Kumbi

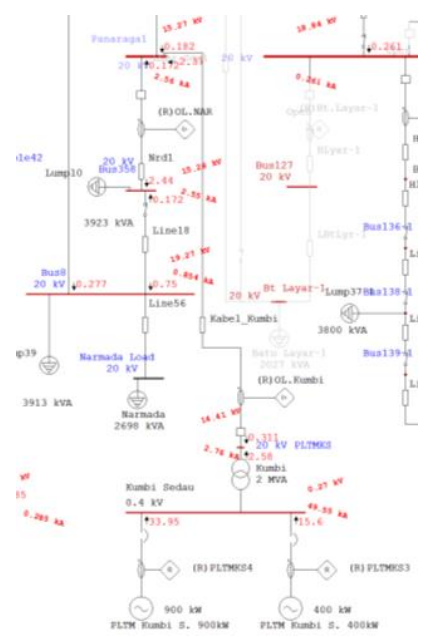

(b). Setelah Interkoneksi Kumbi
Gambar 10 Simulasi Hubung Singkat PLTM Kumbi dengan ETAP

Pada gambar 10 dapat dilihat hasil simulasi untuk gangguan Phasa-Netral sebelum dan sesudah interkoneksi PLTM Kumbi. Dari hasil simulasi ini tidak ditemukan perbedaan yang besar arus hubung singkat yang dihasilkan oleh gangguan Phasa-Netral dibeberapa bus sebelum dan sesudah interkoneksi PLTM Kumbi. Sebagai contoh, pada bus Panaraga arus hubung singkat gangguan Phasa-Netral yang dihasilkan sebelum interkoneksi sebesar 2,52 kA dan tegangan gangguan sebesar 15,21 kV. Sedangkan, setelah interkoneksi arus hubung singkat gangguan PhasaNetral yang dihasilkan sebesar 2,56 kA dan tegangan gangguan sebesar $15,27 \mathrm{kV}$.

TABEL 7

Hasil Simulasi HubUNG SingKat SEBELUM DAN SESUDAH INTERKONEKSI PLTM KE JARINGAN

\begin{tabular}{|c|c|c|c|c|}
\hline \multirow[t]{2}{*}{ Bus } & \multicolumn{2}{|c|}{$\begin{array}{c}\text { Arus Hubung Sebelum } \\
\text { Interkoneksi PLTM } \\
(\mathrm{kA})\end{array}$} & \multicolumn{2}{|c|}{$\begin{array}{c}\text { Arus Hubung Setelah } \\
\text { Interkoneksi PLTM } \\
(k A)\end{array}$} \\
\hline & Fault L-N & Fault 3申 & Fault L-N & Fault 3申 \\
\hline G1 Ampenan & 1.36 & 16.63 & 1.36 & 16,74 \\
\hline Perumnas & 0.48 & 1.56 & 0.48 & 1.54 \\
\hline P. Batudawa & 1.25 & 11.64 & 1.25 & 11.7 \\
\hline Taman & 1.24 & 8.96 & 1.24 & 8.99 \\
\hline GH Panaraga & 2.52 & 4.7 & 2.56 & 4.88 \\
\hline B. Narmada & 0.854 & 13.06 & 0.854 & 13.11 \\
\hline B. Panaraga & 2.51 & 4.69 & 2.55 & 4.87 \\
\hline Kumbi & 2.7 & 4.17 & 2.76 & 4.36 \\
\hline
\end{tabular}

Adapun hasil simulasi arus hubung singkat yang dihasilkan oleh gangguan Phasa-Netral dan 3 (tiga) Phasa dapat dilihat pada tabel 7. Dari tabel tersebut, tidak ditemukan arus hubung singkat yang melebihi rating peralatan (Tabel 2) yang terpasang pada bus terdekat dengan PLTM di sistem interkoneksi lombok.

\section{KESIMPULAN}

Dari hasil kajian yang telah dilakukan, dapat disimpulkan bahwa interkoneksi PLTM Kumbi yang rencananya akan beroperasi pada tahun 2021 layak untuk dilakukan. Produksi energi yang dihasilkan oleh PLTM Kumbi dapat menambah pasokan dari kebutuhan beban pada Sistem Lombok, terutama beban Narmada. Hal ini, didasarkan pada kajian aliran daya dan hubung singkat yang telah dilakukan. Dari hasil kajian tersebut dapat disimpulkan sebagaimana berikut:

1. Tingkat kualitas layanan sebelum dan sesudah interkoneksi,

Dari hasil simulasi, aliran daya sebelum interkoneksi proyek menunjukkan bahwa tegangan pada bus JTM terdekat ke lokasi PLTM Kumbi (bus Panaraga1) adalah $19.233 \mathrm{kV}$ dan tegangan pada akhir pengumpan bus Narmada JTM adalah $19.073 \mathrm{kV}$. Sementara itu, setelah masuknya proyek, nilai tegangan JTM terdekat ke lokasi adalah $19.442 \mathrm{kV}$ dan $19.474 \mathrm{kV}$ untuk pengumpan JTM Narmada akhir. Ini menunjukkan bahwa kualitas tegangan pada pengumpan JTM Narmada masih dalam batasan kriteria operasi yaitu masih diantara 90\% $105 \%$ dari tegangan nominal.

2. Tidak perlu penambahan kompensator,

Karena tegangan di JTM terdekat dengan lokasi proyek masih dalam batasan kriteria operasi. Kemudian kompensator proyek belum dipersyaratkan.

3. Gangguan hubing singkat tidak menghasilkan tegangan berlebih.

Hasil simulasi, saat terjadi hubung singkat pada bus di JTM terdekat dengan lokasi proyek, tidak ada gejala tegangan gangguan yang berlebih seperti yang ditunjukkan pada gambar 10. Sehingga diperkirakan interkoneksi PLTM tidak akan menyebabkan tegangan gangguan yang berlebih.

4. Rating peralatan yang ada harus dapat melebihi kapasitas arus hubung singkat.

Hasil simulasi rangkaian pendek seperti yang ditunjukkan pada tabel 7, menunjukkan bahwa nilai arus hubung singkat tidak melebihi nilai peralatan yang ada.

\section{REFERENSI}

[1] PT PLN (Persero), Rencana Usaha Penyediaan Tenaga Listrik (RUPTL) PT PLN (Persero) 2016 - 2025.

[2] Khan, Shoaib., Industrial Power Systems, Taylor \& Francis Group, LLC, 2008.

[3] PT PLN (Persero), Pedoman Penyambungan Pembangkit Listrik Energi Terbarukan ke Sistem Distribusi PLN, Juli 2014. 
[4] Junior, W. S. D., Power System Analysis, New York: McGraw-Hill, Inc, 1984.

[5] Sadaat, Hadi., Power System Analysis, New York: McGraw-Hill, Inc, 1999.

[6] Stevenson, William D., Elements Of Power System Analysis McGraw-Hill Series in Electrical Engineering. Power and Energy, 1994.

[7] Short, Tom., Electric Power Distribution Handbook, CRC Press LLC, Florida, 2004

[8] Gano, Rimbo,. Pane, Zulkarnaen., Studi Aliran Daya pada Jaringan Distribusi 20kV yang Terinterkoneksi dengan Distributed Generation (Studi Kasus: Penyulang PM.6 GI Pematang Siantar), Singuda Ensikom, Vol.11 No.29/April 2015.
[9] Suyono, Hadi., Hasanah, Rini Nur., Utomo, Teguh., Letik, Markus D., Analisis Stabilitas Sistem Daya pada Interkoneksi PLTMH Ampelgading di Gardu Induk Turen, Jurnal EECCIS Vol. 6, No. 2, Desember 2012

[10] Adhy Kurniawan, 2009. Pedoman Studi Kelayakan Hidrologi, Direktorat Jenderal Listrik dan Pemanfaatan Energi Departemen Energi dan Sumber Daya Mineral.

[11] Kroposki, B., "DG Power Quality, Protection and Reliability Cas Studies," New York, 2003.

[12] Budi Pratama, M., Yusuf, Erwin, Studi Aliran Daya PLTU Kaltim 6 pada Sistem Kaseltentimra. Journal of Science Technology and Enterpreneurship, 1 (1), 76-81. 2019. 